\title{
Sosialisasi Dan Pelatihan Penguatan Pengelolaan Keuangan Desa Pada Desa Oenak Kecamatan Noemuti
}

\author{
Marisa S. B. Seran ${ }^{*}$, Andre Pattipeilohy², Fransiskus Atok ${ }^{3}$ \\ ${ }^{1,2}$ Universitas Timor, Kefamenanu, Indonesia \\ *Corresponding Author: cucanseran@gmail.com
}

Info Artikel Diterima : 24/11/2021 Direvisi: 29/11/2021 Disetujui: 01/12/2021

\begin{abstract}
Village Financial Management is an entire activity that includes planning, implementation, management, reporting and accountability of village finances. The role of the village apparatus in understanding the financial management of the village is very necessary. The purpose of village financial management activities has been stated in Permendagri No. 20 of 2018 which greatly helps the Village Government in understanding the problem of village financial management. The devotional activities were carried out by first holding a socialization of Permendagri Regulation No. 20 of 2018 on Village Financial Management until the assistance of the codefication book of village assets of South Bikomi Subdistrict. The meode used in this devotional activity is in the form of lectures, dialogues, as well as mentoring and practice through technical guidance. The results of this activity are: 1) There is an increase in capacity in the form of understanding by the Village Apparatus in Oenak Village of Noemuti Subdistrict about the role of village apparatus and village financial management in accordance with permendagri Number 20 of 2018.2) Optimization of Village Financial Management for the sake of the realization of the welfare of the village community in Oenak Village, Noemuti District, North Central Timor Regency.
\end{abstract}

Keywords: Village Financial Management, Training, Oenak Village Noemuti Subdistrict

\begin{abstract}
Abstrak. Pengelolaan Keuangan Desa adalah merupakan keseluruhan kegiatan yang meliputi perencanaan, pelaksanaan, penatausahaan, pelaporan dan pertanggungjawaban keuangan desa. Peran aparatur desa dalam memahami pengelolaan keuangan desa sangatlah diperlukan. Adapun tujuan dari kegiatan Pengelolaan Keuangan Desa telah tertuang dalam Permendagri No. 20 Tahun 2018 yang sangat membantu Pemerintah Desa dalam memahami persoalan pengelolaan keuangan desa. Kegiatan pengabdian dilakukan dengan terlebih dahulu mengadakan sosialisasi peraturan Permendagri No. 20 Tahun 2018 tentang Pengelolaan Keuangan Desa sampai pada pendampingan adanya buku kodefikasi aset desa Kecamatan Bikomi Selatan. Adapun meode yang digunakan dalam kegiatan pengabdian ini adalah dalam bentuk ceramah, dialog, serta pendampingan dan praktik melalui bimbingan teknis. Hasil dari kegiatan ini yakni: 1) Adanya peningkatan kapasitias dalam bentuk pemahaman oleh Aparatur Desa yang ada di Desa Oenak Kecamatan Noemuti tentang peran aparatur desa dan pengelolaan keuangan desa yang sesuai dengan permendagri Nomor 20 tahun 2018. 2) Optimalisasi Pengelolaan Keuangan Desa demi terwujudnya kesejahteraan masyarakat desa yang ada di Desa Oenak Kecamatan Noemuti Kabupaten Timor Tengah Utara.
\end{abstract}

Kata Kunci: Pengelolaan Keuangan Desa, Pelatihan, Desa Oenak Kecamatan Noemuti.

How to Cite: Seran, M. S. B., Pattipeilohy, A., \& Atok, F. (2021). Sosialisasi Dan Pelatihan Penguatan Pengelolaan Keuangan Desa Pada Desa Oenak Kecamatan Noemuti. Prima Abdika: Jurnal Pengabdian Masyarakat, 1(4), 219-226. https://doi.org/10.37478/abdika.v1i4.1365 under a Creative Commons Attribution-ShareAlike 4.0 International License.

\section{Pendahuluan}

Pemerintah telah memiliki panduan penyusunan dan mekanisme pengelolaan keuangan desa yang terbaru yakni pada Permendagri Nomor 20 tahun 2018 tentang Pengelolaan Keuangan Desa dimana Permendagri tersebut hasil perubahan dari Permendagri No. 113 tahun 2014 tentang Pengelolaan Keuangan Desa. Permendagri tahun Nomor 20/2018 menjadi acuan terbaru bagi perangkat desa dalam hal desa untuk mengelolaan kepemilikan keuangan desa di dalam APBDes yang memuat 1) Perencanaan; 2) Pelaksanaan; 3) Penatausahaan; 4) Pelaporan; Pertanggungjawaban Pengelolaan Keuangan Desa. 
Sebagaimana Permendagri Nomor 20 tahun 2018 disebutkan bahwa Asas Pengelolaan Keuangan Desa pada pasal 2 ayat (1), pengelolaan dana desa berdasarkan asas transparan, akuntabel, partisipatif serta dilakukan dengan tertib, dan disipilin anggaran. Pemegang Kekuasaan Pengelolaan Keungan Desa (PKPD) haruslah mewakili pemerintah dalam hal pengelolaan keuangan desa. Oleh karena itu pengelolaan keuangan desa tentu menjadi kewenangan Kepala Desa sebagai PKPD dimana kepala desa harus memahami dengan baik peraturan perundanga-undangan terkait pengelolaan keuangan desa. Persoalan yang muncul jika kepada desa dan perangkat desa lainnya tidak memahami dengan baik bagaimana pengelolaan keuangan desa sampai pada penyusunan laporan pertanggungjawaban dimana kepala desa wajib menyampaikan laporan pertanggungjawaban realisasi pelaksanaan APBDesa paling lambat satu bulan setelah akhir tahun anggaran serta laporan realisasi dan laporan pertanggungjawaban pelaksanaan APBDesa kepada bupati/walikota melalui camat. Belum lagi dengan dana desa yang tengah digulirkan pemerintah yang sekian banyak jumlahnya tersebut yang harus dikelola oleh desa tentu menjadi tantangan tersendiri bagi kepala desa dalam mengelola keuangan desa berdasarkan asas-asas pengelolaan keuangan desa. Banyaknya kasus kepala desa yang khawatir dalam pengelolaan dana desa atau keuangan desa disebabkan karena belum memahami secara maksimal dalam pengelolaan keuangan desa.

Banyak juga ditemui dalam berbagai kasus bahwa terkadang banyak desa yang belum cukup cakap dalam mengelola dana desanya. Dimana sering ditemui permasalahan terkait dengan administrasi terkait dengan pengelolaan keuangan desa yang ada. Hal ini juga merupakan salah satu tantangan besar karena dari segi sumber daya manusianya masih perlu diperkaya lagi. Terkait hal inilah aparatur desa sangat perlu diperkaya dengan pengetahuan dan ketrampilan sehingga dalam mengelola keuangan desanya dapat tersusun secara rapi, sistematis, efektif serta efisien.

\section{Metode Pelaksanaan}

Adapun metode dalam pelaksanaan kegiatan pengabdian yaitu dengan metode ceramah, dialog serta pendampingan dan praktik melalui bimbingan teknis;

1. Kegiatan pertama dilakukan melalui observasi dan diskusi kepada pihak aparatur desa Oenak terhadap Persoalan Pengelolaan Keuangan Desa dan terkait sasaran kegiatan;

2. Kegiatan kedua dilakukan melalui seminar dan sosialisasi Permendagri No. 20 Tahun 2018 Pengelolaan Keuangan Desa pada Desa Oenak Kecamatan Noemuti;

3. Pendampingan terkait Pengelolaan Keuangan Desa termasuk adanya Buku Pembantu Bank, Buku Pembantu Pajak dan Buku Pembantu Panjar Desa Oenak Kecamatan Noemuti Kabupaten Timor Tengah Utara.

Adapun kegiatan diadakan langsung di Ruang Aula Kantor Desa Oenak dengan melibatkan perangkat desa. Adapun rincian peserta Kepala Desa, Sekretaris Desa, Kaur Keuangan, Ketua BPD, Sekretaris BPD dan Anggota, Kepala Seksi, Kepala Dusun 1, Kepala Dusun 2, dan 4 Tenaga Administrasi Desa. 


\section{Hasil dan Pembahasan}

Adapun proses kegiatan pengabdian Pengelolaan Keuangan Desa ini yaitu dibagi dalam 3 tahap yakni: 1) Diskusi terhadap Persoalan Pengelolaan Keuangan Desa; 2). Workshop Pengelolaan Aset Desa; 3) Pelatihan dan Pendampingan Pengelolalaan Keuangan Desa. Ketiga tahapan itu akan dijelaskan sebagai berikut:

\section{Tahap Pertama}

Kegiatan dimulai dengan diskusi dengan Pihak Aparatur Desa mengenai apa yang menjadi kendala dan persoalan teknis pengelolaan keuangan desa di Desa Oenak Kecamatan Noemuti. Kegiatan ini berlangsung kurang lebih sebulan dengan terus menjalin hubungan komunikasi dengan bapak Desa terkait persoalan Pengelolaan Keuangan Desa. Selain itu dilakukan observasi di lapangan dan wawancara langsung dengan perangkatperangkat desa di Pemerintahan Desa pada Desa Oenak Kecamatan Noemuti Kabupaten Timor Tengah Utara.

Setelah melalui diskusi yang cukup intens dengan bapak Desa dan aparatur desa diperoleh informasi bahwa persoalan pengelolaan desa ini lebih kepada ketidaksengajaan perangkat desa dikarenakan kurang paham mengelola keuangan desa yang baik. Dimana pengelolaan keuangan desa dimulai dari perencanaan, sampai pada pertanggungjawababnya. Yang paling banyak terjadi mengenai penatausahaan dan pelaporan. Aparatur desa banyak yang mengabaikan mekanisme pentingnya penatausahaan keuangan yang baik hingga pelaporannya sehingga dalam pembuatan laporan akhir menjadi sedikit terkendala. Sebagai contoh dalam persoalan penatausahaan keuangan desa dimana bendahara desa terkadang masih kurang tertib dalam membukukan setiap pembelanjaan desa. Dan terkadang pula sering terjadi kesalahan dalam menginput kode akun sub kegiatan desa. Dari beberapa persoalan yang diperoleh inilah yang menjadi dasar pelaksanaan workshop pengelolaan keuangan desa untuk dibahas dan didiskusikan secara bersama.

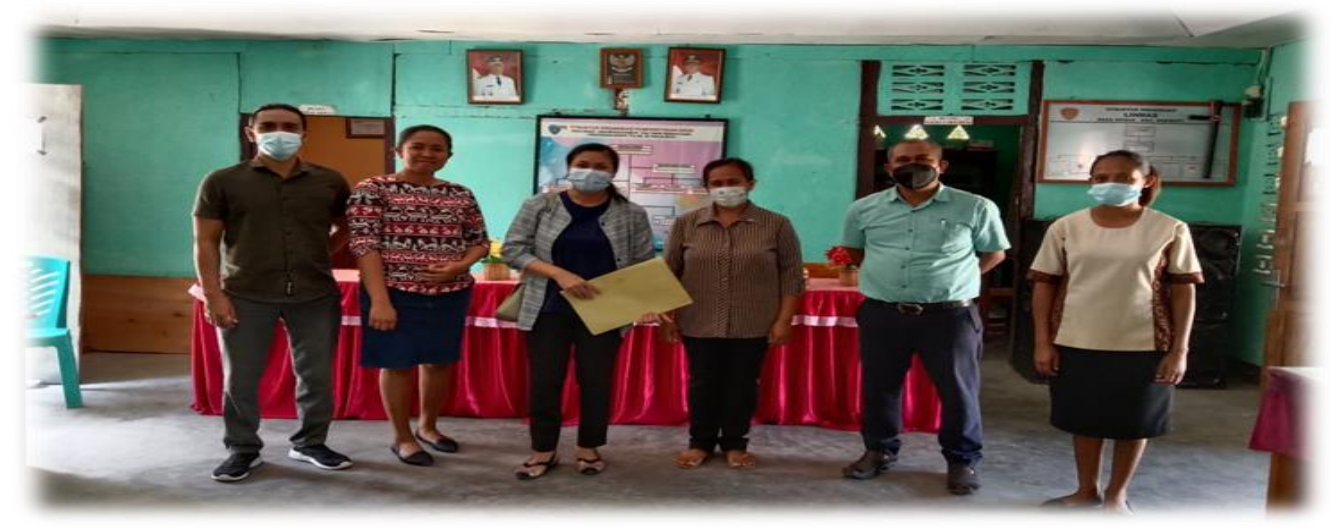

Gambar 1. Foto Diskusi dengan Pihak Aparatur Desa Oenak Kecamatan Noemuti Kabupaten Timor Tengah Utara Terkait Persoalan Teknis Pengelolaan Keuangan Desa

\section{Tahap Kedua}

Kegiatan tahap kedua ini yakni workshop Pengelolaan Keuangan Desa, kegiatan berlangsung di Ruang Aula sekaligus menjadi ruang kerja Kantor Desa Oenak pada tanggal 04 - 05 Agustus 2021 dengan rincian peserta yang terdiri dari 14 orang yang ada yakni Kepala Desa, Sekretaris Desa, Kaur 
Keuangan, Ketua BPD, Sekretaris BPD dan Anggota, Kepala Seksi, Kepala Dusun 1, Kepala Dusun 2, dan 4 Tenaga Administrasi Desa.

Adapun rincian kegaitan yakni sebagai berikut:

a. Pertama pembahasan mengenai pendalaman persoalan dan diskusi tindak lanjut solusi terhadap permasalahan teknis pengelolaan keuangan desa dan kegiatan dilanjutkan dengan pemaparan materi terkait dengan pengelolaan keuangan desa. Kegiatan terlebih dahulu buka oleh Kepala Desa Oenak setelah itu dilanjutkan dengan memberikan pre test terhadap pemahaman awal terkait pengelolaan aset desa. Selanjutnya dilakukan diskusi dan pemaparan materi pengelolaan keuangan desa sampai kegiatan selesai.

b. Dari hasil pree test ditemui bahwa pemahaman aparatur desa terakit dengan pengelolaan keuangan masih dibilang minim. Hal ini didapat dari 20 perangkat desa yang megikuti kegiatan ini 15 orang diantaranya masih belum memahami dengan baik terkait dengan pengelolaan keuanan desa yang sesuai dengan aturan yang berlaku. Sedangkan 5 diantaranya sudah cukup baik dalam memahami pengelolan keuangan desanya.

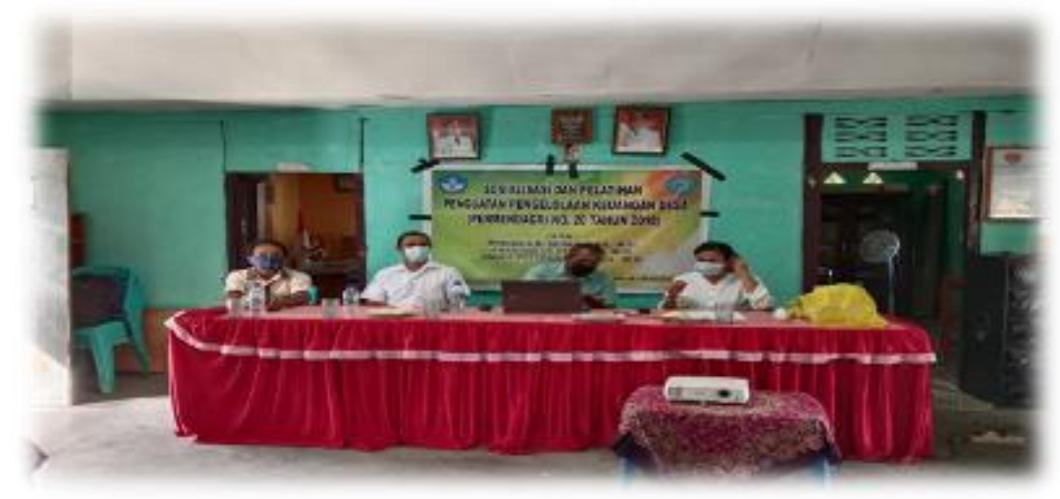

Gambar 2. Pembukaan Kegiatan Sosialisasi Oleh Kepala Desa Oenak

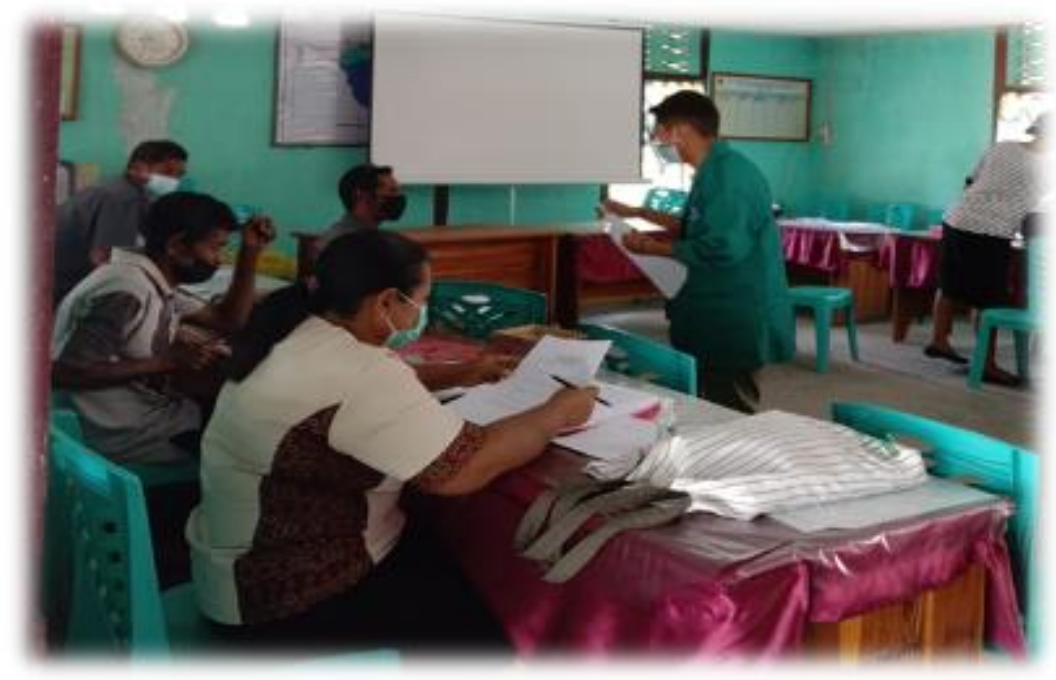

Gambar 3. Pelaksanaan Pre Test Bagi Perangkat Desa Oenak 


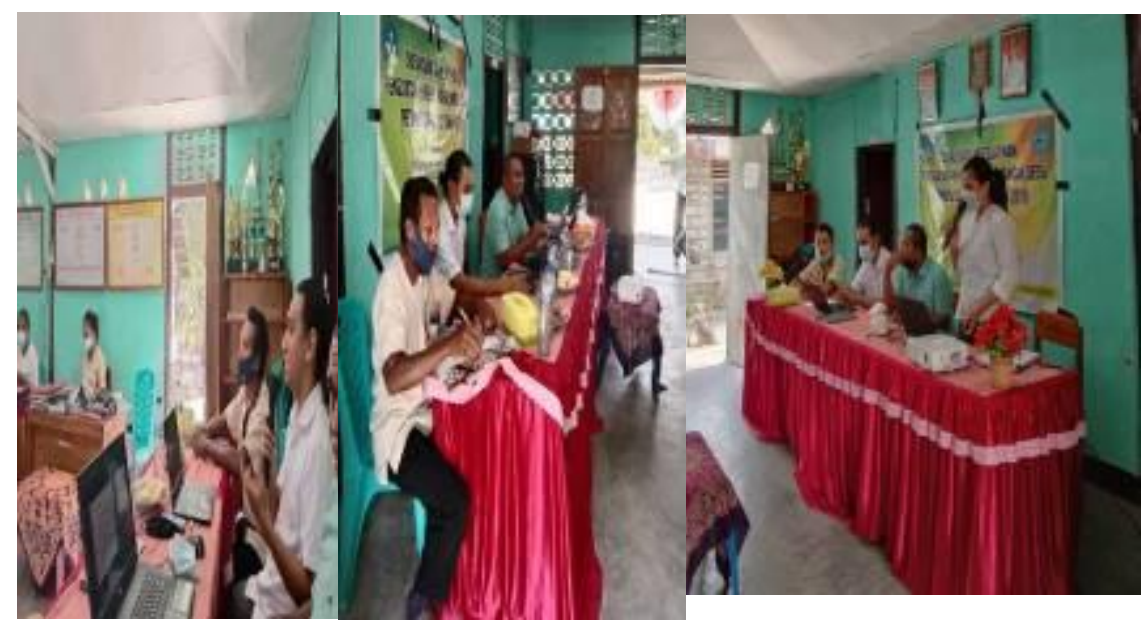

Gambar 4. Pemaparan Materi Terkait Pengelolaan Keuangan Desa

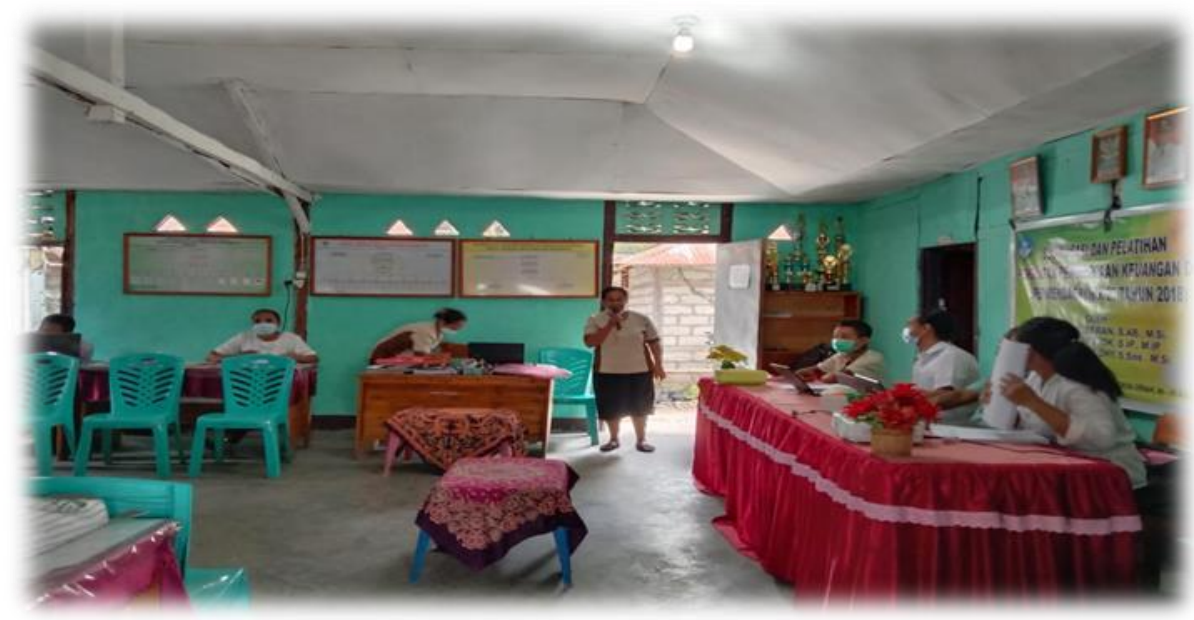

Gambar 5. Diskusi dan Tanya Jawab Terkait Pengelolaan Keuangan Desa

\section{Tahap Ketiga}

Pada tahapan ini dilakukan Pendampingan Pengelolalaan Aset Desa terhadap tindak lanjut persoalan pengelolaan aset desa. Dalam pendampingan ini lebih difokuskan pada hal yakni; Penatausahaan Keuangan Desa berupa Buku Kas Umum, Buku Pembantu Bank, Buku Pembantu Pajak dan Buku Pembantu Panjar Desa. Dalam pendampingan penatausahaan keuangan desa dijelaskan pada Permendagri No. 20 Tahun 2018 bahwa mengenai penatausahaan keuangan. Adapun Penatausahaan yang sesuai dengan Peremendagri Nomor 20 Tahun 2018 adalah:

(1) Penatausahaan Keuangan Dilakukan Oleh Kaur Keuangan Sebagai Pelaksana Fungsi Kebendaharaan.

(2) Penatausahaan Dilakukan Dengan Mencatat Setiap Penerimaan Dan Pengeluaran Dalam Buku Kas Umum.

(3) Pencatatan Pada Buku Kas Umum Ditutup Setiap Akhir Bulan.

(4) Kaur Keuangan Wajib Membuat Buku Pembantu Kas Umum Yang Terdiri Atas: 
(5) Buku Pembantu Bank, Merupakan Catatan Penerimaan Dan Pengeluaran Melalui Rekening Kas Desa

(6) Buku Pembantu Pajak, Merupakan Catatan Penerimaan Potongan Pajak Dan Pengeluaran Setoran Pajak

(7) Buku Pembantu Panjar, Merupakan Catatan Pemberian Dan Pertanggungjawaban Uang Panjar

Di lapangan kemudian muncul persoalan dikarenakan masih adanya kesalahan Kaur Keuangan dalam mengadakan pencatatan pada Buku kas serta kurang mengingat akun kode rekening dari setiap sub kegiatan. Hal ini yang kemudian menjadi pendampingan tim di lapangan dengan terlebih dahulu memberikan panduan kodefikasi pengelolaan keuangan desa yang sesuai dengan Kepmendagri. Setelah itu kemudian dibantu untuk menginventarisir setiap nota pembelanjaan desa dengan baik sehingga dalam menatausahakan jenis pengeluarannya sesuai sehingga dapat membuat laporan akhir pelaksanaan kegiatan dengan baik. Kegiatan ini intensif Tim lakukan pendampingan sampai pada selesainya Pengisian Buku Kas Umum, Buku Pembantu Bank, Buku Pembantu Pajak dan Buku Pembantu Panjar sesuai dengan tata aturan pengkodean akun rekening dari Permendagri Nomor 20 tahun 2018.

Dari tahapan ini tim terus kiat melakukan pendampingan terhadap para perangkat desa. Sehingga para perangkat desa pun mulai memahami akan prosedur pengelolaan keuangan desa yang benar sesuai dengan aturan permendagri nomor 20 Tahun 2018 tentang Pengelolaan Keuangan Desa. Sehingga para perangkat desa sudah memiliki dokumen pendukung yang sesuai dengan aturan yang berlaku.

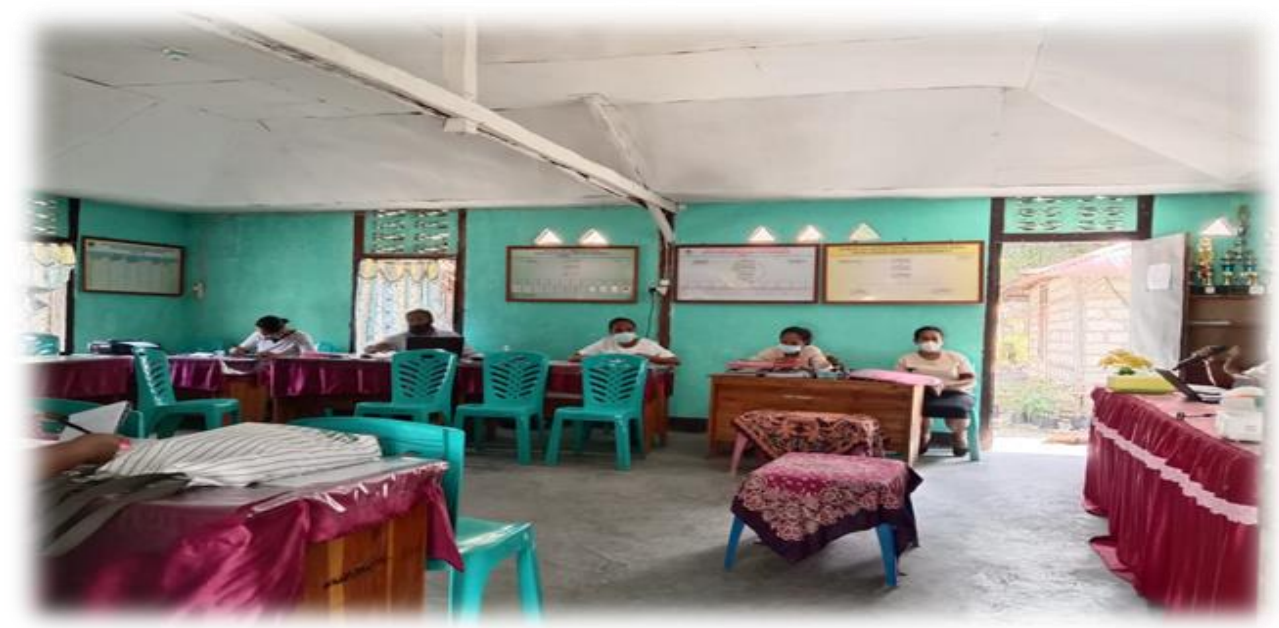

Gambar 6. Bimbingan Teknis Terkait Perencanaan Hingga Pelaporan Pertanggungjawaban Keuangan Desa 


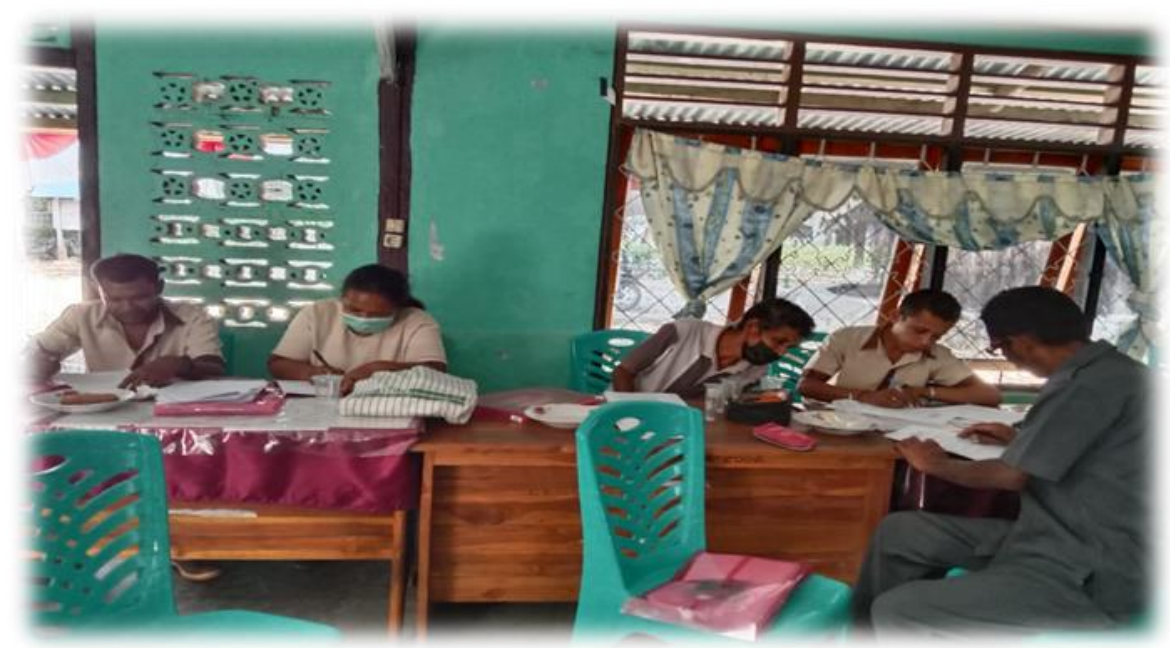

Gambar 7. Pelaksanaan Post Test bagi Perangkat Desa Oenak

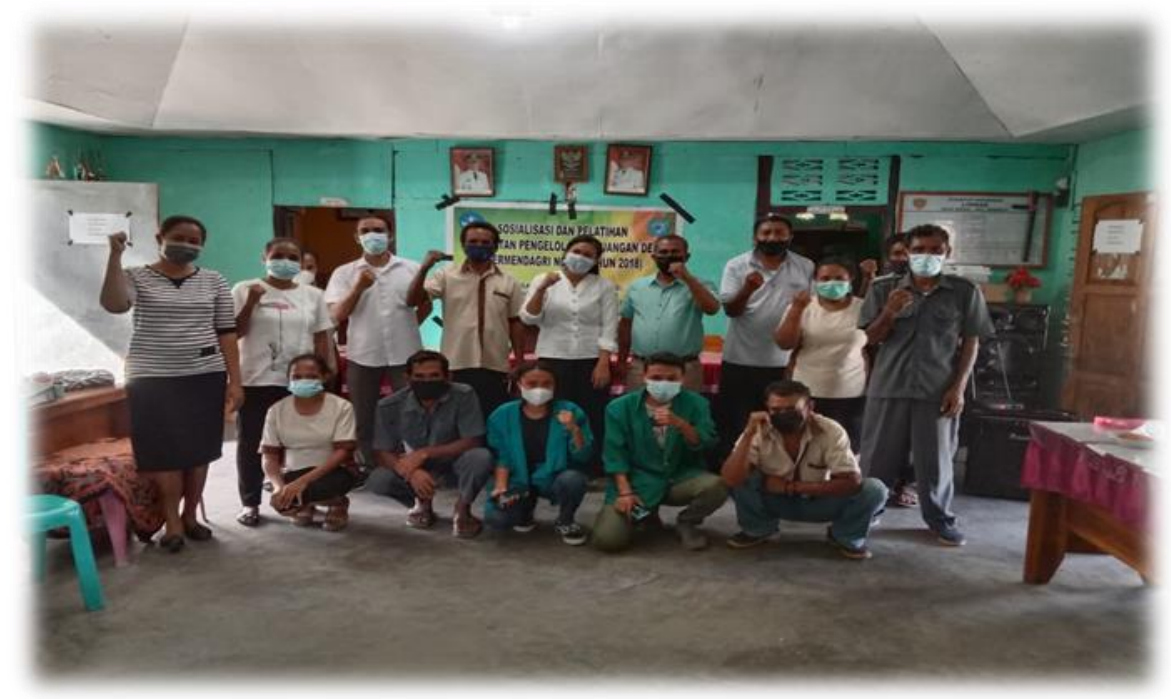

Gambar 8. Penutupan Pelaksanaan Kegiatan Sosialisasi dan Pelatihan Penguatan Pengelolaan Keuangan Desa di Desa Oenak

\section{Simpulan dan Tindak Lanjut}

Kegiatan Pengabdian kepada masyarakat berupa Sosialisasi Dan Pelatihan Pengelolaan Keuangan Desa Di Desa Oenak Kecamatan Noemuti diperoleh hasil sebagai berikut:

1) Adanya peningkatan kapasitias dalam bentuk pemahaman oleh Aparatur Desa yang ada di Desa Oenak Kecamatan Noemuti tentang peran aparatur desa dan pengelolaan keuangan desa yang sesuai dengan permendagri Nomor 20 tahun 2018.

2) Optimalisasi Pengelolaan Keuangan Desa demi terwujudnya kesejahteraan masyarakat desa yang ada di Desa Oenak Kecamatan Noemuti Kabupaten Timor Tengah Utara. 
Dari kegiatan ini akan terus mendapatkan perhatian dan bimbingan secara berkelanjutan.

\section{Daftar Pustaka}

Nurcholis, H. (2011). Pertumbuhan \& penyelenggaraan pemerintahan desa. Erlangga

Mutalib, M. T. (2016). Pengelolaan Keuangan Desa/Dana Desa Menurut Undang-Undang Desa. Skripsi. Universitas Islam Indonesia: Yogjakarta

Indonesia, R. (1979). Undang-Undang No. 5 Tahun 1979 tentang Pemerintahan Desa. Jakarta: Sekretariat Negara.

Indonesia, R. (2004). Undang-Undang Republik Indonesia Nomor 32 Tahun 2004 Tentang Pemerintahan Daerah. Jakarta (ID): RI.

Yustisia, T. V. (2015). Undang-Undang Nomor 6 Tahun 2014 Tentang Desa dan Peraturan Terkait. Visimedia.

Kementerian Dalam Negeri (2018). Peraturan Menteri Dalam Negeri Nomor 20 Tahun 2018 tentang Pengelolaan Keuangan Desa

Wardoyo, Hasto. 2015. Penguatan Pengelolaan Keuangan Desa dan Optimalisasi Peran BUMDes. Yogyakarta: Universitas Atma Jaya 